\title{
Statute Law and Criminal Proceedings over the Years 1944 - 1992 in Albania
}

\section{Ferdinand Elezi}

\author{
ferdinandelezi@yahoo.com
}

\author{
Doi:10.5901/ajis.2015.v4n1p247
}

\begin{abstract}
Criminality has existed since the constitution of the state every society in all stages of its growth has responded and called for certain positions towards behaviors and attitudes that conflicted with its stakes and the reigning political class. The history of the evolution of the criminal process, criminal evidence, proof search tools and criminal jurisprudence in general, presents not just historical but also to sympathize and know this operation better at all phases of its evolution. Evidence and the process of proving, has been further developed by social relations, political conditions, economic and social evolution that cause existed in certain phases of our societal evolution. During the period of years 1994 -1992, legislation changes have occurred with various developments and in contradiction not only to criminal proceedings and the legislation of the countries of Western Europe, but with the Eastern countries, as well. Criminal and criminal procedural legislation of Eastern countries did not recognize regression and serious violations of the criminal process rights, as the criminal process encountered over the years 80 s, with legislation adopted based on the 1976 Constitution. Criminal Procedural legislation in the Republic of Albania, underwent changes with the espousal of the Criminal Procedure Code, Law No. 7905 dated 21.03.1995 by aligning it to the democratic procedural systems with adversarial character, full equality of the parties at trial and with enhanced rights of criminal prosecution bodies during the preliminary investigations, which are verified and determined by the tribunal.
\end{abstract}

Keywords: Criminal Procedure Code, tribunal, statute law,

\section{Criminal Process in the Years $1944-1953$}

During this full stop there was no the legal adjustment specific to penal process and in particular for evidence and search of criminal evidence tools. Prosecuting organs and the tracing ones conducted checks of sequestering under the command orders, or tracking forces without any formal legal procedure or even sporadically according to their subjective assessment. This point is characterized by serious violation of freedoms, human rights, arbitrary and extreme political violence, perpetrated by state organs, justified as a dictatorship of workers, people and the proletariat achieving and maintaining the victories of the warfare and the new social club.

Several criminal processes assembled with forged evidence and facts were taken against political and public personalities and intellectuals of the fourth dimension. Here we can mention penal process against 28 members or as it was visited group of deputies, criminal processes against the clergy, especially the Catholic ethos. Revelations in recent years in terms of pluralist democracy show that some of the litigation at the time was not based on evidence, and some of those accused of criminal offenses against the country, were to be innocuous. Such litigation against former MPs etc, has infringed the rights and freedoms for the right to exist. On 03/14/1946 the Constitutional Assembly adopted the Statute, the Constitution of the Albanian Republic which, then dished out as the chief author of criminal crimes and criminal procedural legislation. Although Article nr. 19 of the Statute stipulated that: "No one can be convicted of a penal offense that was not expressly foreseen guilty and sentences have not been sure of this jurisprudence. The punishment could be ordered by the court pursuant to this law, "This important rule was hardly implemented and, in many cases, human rights and fundamental freedoms were severely weakened. By order of the Presidium of the National Assembly No. 392 dated 24.01.1947, its Article 3 stated that "the previous provisions shall apply as legal rules when they do not contradict with the spirit of new democracies and legal acts of the national government"

The judicial organization became scale prefectures, Prefectures and High Court. The Supreme Court consisted of ten members organized into two colleges as well as the General Council, which were part of all its members. Change of legal arrangements was made by the Law No. 1284 dated 06.09.1951 in which, it was determined the selection of judges and lay judges of the people voting were defined and limited powers of military courts. The people's courts in the first instance judge, was created district courts, which considers the second instance, while serious crimes as courts of first instance.

Must be said that in general all legislation enacted legislation based on eastern countries, mainly Soviet, it was the 
function of the Party's policy, and the few formal rules that were predicted in practice almost never applied in particular to the works offenses which are considered as crimes against the state. Criminal processes that time were characterized by gross violations of fundamental rights and freedoms of the individual with the right to life. This remained until the acceptance of the entry into force of the Code of Criminal Procedure of 1953, approved by Law No. 1650 dated 30.03.1953 of the National Assembly of the Republic Albania.

\section{Criminal Process under the Penal Procedure Code of 1953}

The Criminal Procedure Code was adopted by Law No. 1650 dated 30.03 .1953 of the National Assembly. This code consisted of 364 articles, entered into force on 06.01.1953. These modifications were induced to the Law No. 1776 dated 03.12.1953 and the Law No. 2805 dated 04.12.1958, and has been in force until the date 04.01.1980 with the entry into force of the criminal procedure code adopted by Law No. 6069 dated 25.12 .1979. Although it stood for the inquisitive system, it must be said that for the first time, clearly fully criminal procedural rules have been set. A judicial system under this code provided district and military tribunals in the foremost stage, the circumference and the Supreme Court in the second level (Article nr 25) which account for some issues as a tribunal of second instance of legality issues, and as a court of first instance for certain issues related primarily to the subject being proceeded and to certain crimes, as well. Main procedural principles were predicted in the beginning part of this code as: trial detention twice for the same offense, the open door trial, the equivalence between the parties out in the judgment, the principle of presumed innocence, in which, for the very first time, it has been envisaged that the court shall return its determination of the duties and rights of procedural subjects based on the evidence received and reviewed from the hearing, session, and so along.

Criminal prosecution was led by the prosecuting officer who had the right to conduct investigations themselves and be facilitated by other bodies of tracing investigation, under the guidance and control of the prosecuting attorney. This code anticipated that the prosecution directly, was exercised by the court itself when, during the court sitting, it was revalued as well as going down the precautionary measures mainly against defendants. Prosecutors were organized the district prosecutor offices in the first case, the county prosecutors in the second case and prosecutors of the General Prosecutor. Probe as an investigative body conducting activities under the guidance of the prosecutor, was formed at the district prosecutor, state insurance investigators, county investigators and research workers at the General Prosecutor. Over the actions of law enforcement organs, it has been noted the right of appeal to the prosecutor, on the prosecutor to the highest one against the court decision to the senior courtyard. Criminal proceedings are underway, mainly by the Attorney, the Investigator and the Court (Tribunal) itself. First investigative operations were transmitted by the tracking bodies (security authorities, police, inspectorates of control etc...) As well as investigating authorities. The procedural provisions on evidence were foreseen and regulated by articles 60-85 of this Code and by the provisions scattered throughout its chapters. Article 60 determined the understanding of criminal evidence, whereas article 61 defined the types of evidence, namely; statements of witnesses, defendants, expert views, material evidence of writing documents and proceedings in the court investigation operations.

Interceptions, observations, photographs and private video footage though, applied by tracing and investigation bodies (authorities) were not foreseen as sources or evidence in criminal trials. These research evidence tools were used by investigating state security and organs of traceability for crimes against the nation. Application of these tools was made a discreet operational activity which consequently was determined by other legal acts issued by the Ministry of Interior as well as determinations of the political office of land. The following provisions of this code specified the procedural rules regarding the discovery, learning, management, assessment and verification of evidence. Not a single evidence had predetermined value in those provisions; assessment of the evidence was cleared by the court after having met and marked them on judicial review of the case.

This code envisioned procedural rules of evidence as proof, witnesses liabilities, cases of witness incompatibility (physical and mental disability), and thus on. The defendant has a constitutional right not to testify referable to the connectivity with the accused or due to the preservation of confidentiality is not known in any shell. Furthermore the Defender of the defendant could be named as a witness against state criminal offenses under the Criminal Code in power, The twelfth chapter of section II of this code set out procedural rules to question witnesses and experts. Under these projections, the viewer was forced to testify about every fact and circumstance related to the investigation, also was announced for criminal responsibility in case of false testimony or refusal to take the stand. Opposition and its effects were not presented as a origin of evidence in itself, but in article 161/2 of the Code recognizably, was noted the right: "In case of need the investigator makes confrontation between witnesses". Predictions were made on the formal way of the act of testimony written form and how it was all proceeded in cases of deaf-mute witnesses, maintain in secrecy and thus 
along.

Statements and explanations of the defendants were foreseen as evidence of the defendant himself and the other defendants, as well. Nevertheless, this provision was envisaged that the defendant cannot be compelled to speak, a anticipation which was never used in exercise. In addition to, article 138 stipulated that "the questionnaire on the defendant starts commissioning to tell everything he-she knows about the subject. Having spoken, the defendant is then being asked questions. The statements, the questions asked and the responses presented by the defendant are entirely recorded during the test. ". This period was characterized by grave violations of defendants' rights, the use of physical and psychological violence usually applied in almost all investigative processes. Emphatically, should be claimed that despite the prohibitive provisions of the criminal procedural provisions and criminal law content, this situation extended until the kickoff of the democratic process in the state. During this period, cases of violence and the usage of torture against the defendants were often excused with the purpose of fighting opponents of national authorities and saboteurs, as were commonly perceived as the political pursuits of war against political opponents and so on.

In this chapter the expertise as evidence in criminal trials was set and ordered. Such provisions stipulated the right of investigation and trial, authorities to access the human activity of the procedural operations, the obligation of expertise, experts had to accomplish, their duty and reward for the work done by them or witnesses in the operation. In acquiring and management of such trial it is not foreseen the obligation of notification to the accused or his right to ask questions about the expertise. Article 167 envisaged that the defendant possessed the right of asking an expert assigned by him, to participate in the expertise. Adoption of this demand depended on the investigator's decision issued in the shell.

Evidence and expert view as criminal evidence is governed by articles 160-172 of the Penal Procedure Code, this evidence was formally carried through the query process of both expert and witness. The testimonies of evidentiary value were obtained during the probe, they were turned over to the investigators ahead, he began looking into the subject, while expert opinion was mostly selected from the interrogation verbal process but also by special act drafted by the expert. In the case of experiments with some experts was the routine of penning. In lawsuits of making experiments with several experts, the expert analysis was supplied in written form, but experts were not authorized issuing it that direction. During the adjudication of the case, court administered witnesses and experts as evidence during the investigation or directly to trial.

Reading the material evidence is given in subdivision 77 in which each item or document concerning the issue is closed. Rules for receiving, managing and documenting the physical evidence of the subjects, mainly of technical character were generally limited. No guarantee was applicable for people whom evidence or other availabilities had been removed. Neither the right of a particular complainant of the holder or possessor of the item to oppose obtaining (sequestration) of an object, a document did exist. Article 80 stipulated court obligation to inflict on the material evidence, seized and passed to the state all crime commitment objects and instruments and any benefit derived from or being assured.

Lookup tools, evidence, seizures and the insight, were envisioned by the provisions of chapters XIV and XV of the code.

Controls, reviews, seizures were carried out by the investigator without any procedural rules of guarantees for people who felt violated under these search tools. The investigator any freely and without restriction made their conclusion to perform available. The tab (control) outcomes of the inspections and seizures were reflected in the relevant minutes compiled by the investigator in the presence of trusted people.

Granting to the code, it envisaged the right of the court to perform or go over the seizure of items and exhibits during the tribulation. Specific provisions predicted that the placement and other facilities examination could be done by the courtyard itself. There have never been legal forecasts carried out by the tribunal during the trial issue of controlling as a hunting tool. Principles of procedure in courts of first instance were envisioned by the procedural provisions of chapter XX, sections 225 to 272 of this code. It should be stated that the trial process rights of the parties in the process of bringing about a balance had their tendency, but practically the court assessed the evidence administered by the investigating authorities during the investigation of the event. Legal acts issued during the $60 \mathrm{~s}$ on the abolishment of the Ministry of Justice Decree No. 4277 dated 06.20.1967, the law "On judicial organization in NATIONAL REPUBLIC OF ALBANIA" No. 4406 seen on 24.06 .1968 brought significant regression in the relation of criminal process and processes themselves, in grave violation of the procedural rights of masses in charge with as well as paving the way for arbitrariness and abuse especially on investigative bodies Law approval of no. 5139 on 30.01.1974 "On the unification of the law enforcement organs" not exclusively produced the conditions for further increase in abuse and infringement of citizens' rights and exemptions but also helped the prosecution office in conducting and conducting investigations. Disregarding the above mentioned, criminal legislation of this period took on a substantial part in the formation of a modern criminal 
process, with clearly defined procedural rules which influenced crime reduction in particular, the crime of murder, larceny and so on In relation to procedural legislation of 1980 that resulted in the most comprehensive forecast of institutes and procedures rigorously defined. There was a great deal more democratic character than the successor 1980; this reflected especially in procedural rights and responsibilities of the parties and the whole criminal process.

\section{Criminal Process under the Penal Procedure Code of 1980}

Code of criminal procedure adopted by Law No. 6069 on 25.12.1979 entered into force on 01.04 .1980 replaced the previous code of criminal procedure 1953, and was divided into the general and specific part (in which investigation and trial were included). In general provisions of this Code section were defined; content, assignments, fundamentals, principles and subjects of criminal procedural legislation. This code and all legislation of that period relied on the Constitution of 1976 accounted regression compared with existing legislation; it was a clear expression of fundamental rights and citizens freedoms violations, inequality procedural subjects prescribed by law. Characteristic of this code is defective and overall provisions made thus leaving a complimentary way to arbitrary actions without any routine, without any obligation provided in the proceeding for notifying the affected parties, the liability to be informed, and the right to invoke it.

Forecasts of this code came as a complete contradiction with democratic of criminal processes, expressed in the following features;

Sanctioning court dependency, prosecution and investigation bodies of the state party by law. In parts 3 and 4 of these code principles such as leadership from party policy, class struggle, and line measures were known.

- No formally recognized democratic principles of the criminal process as equalization between parties, innocence presumption, a defense lawyer, being able to speak up, trial evidence etc.

Excluded prosecution from performing and directing investigative activity, inquiries of investigation were charged with unrestricted and uncontrolled righting not only by the prosecution but also by the courtyard.

- Court had no procedural right to settle on the illegal activities of investigative bodies during cases, investigations, any appeal against the actions or conclusions of the investigators were analyzed by the investigative authorities itself.

Annulment of the acts or evidence was not known and envisaged, as a resolution of procedural actions performed illegally or unlawfully. Article 14 intended formal right of the criminal process participants to present evidence, requiring completion of the investigation, and the appeal against investigators and court decisions.

The general significance of the evidence provided in Article 15 of this code which test considered all the data contained in the form provided by this code, and that served to corroborate whether or not the offense, the defendant being guilty or not, personality and its consequences for the crime. As source of evidence under Article 16 were considered witnesses statements, defendants, expert opinions, exhibits and documents. Obtaining and assessment of evidence, consistent with the investigator and the court was based on the jurisprudence and their socialist judicial conscience do not limit any obligation or binding procedural form to be followed and implemented and assessment is based on inner conviction of court investigators.

Testimony as proof was provided and established by articles 19, 20 and 21 of the Code. It was made to handle the investigation of the shell, the witness testified before investigators and evaluators. A witness obligation to testify has been an expectation and criminal liability in case of false testimony or not showing. Juvenile witnesses should be interviewed in the bearing of a teacher or legal representative. Testimony excluded people with physical and mental handicaps. In articles 80 and 81 rules of interrogation of witnesses and the rights of the witness were established. These two provisions determined that the witnesses were questioned by the detective or the court separately for the facts and circumstances related to the matter being investigated and prosecuted as well. Article 31 made predictions for deaf witness query. Their instructions were recorded I along with frequently asked questions and explanations given by the spectator. As percentage of the inquisitorial system testimony was formed as evidence at the time of its reception by the investigator and administered as such by the court in the proceedings with the same value as the testimony given at trial.

The claims of the defendants were considered evidence in criminal trials, in this capacity they were needed after the charges were declared. Flagrantly the question of juvenile offenders was allowed without the presence of defense, anticipating the possibility of the bearing of a teacher or other individual who can serve the minor while being interviewed.

Under Section 23 claims of the defendants were considered as penal evidence as any other evidence, despite his explanations and attitude in the audition session. The defendant query was under the provisions of article 78 of this code, it did not explicitly stipulate his right to answer a question and offer explanations. Article 136/3 of the Code envisaged the right of the court to interpret the statements of witnesses for administering them as evidence when the defendant declined 
to make explanations.

Going over as evidence was established and envisaged by articles 25 and 26 of this code. In expert testimony to determine that were executed by specialists of the state institutions which have technical and scientific knowledge. In contrast to the previous code had to afford their feeling in writing form whose conclusions were considered as evidence in criminal trials. Article 82 determined the disposition of court cases to perform expertly, these provisions stipulated the obligation to advise the defendant of committing this expertise as well as the defendant's rights to exclude the expert, the appointment of other experts and paved other questions expertise. Those rights which had merely a formal case, their execution was rather rare in practice, this also because of the intellectual level, the lack of assistance and protection by lawyer etc.

Should be claimed that for expertise and cesarean as sources of evidence, legal provisions are wholly deficient, and leave room conduct an abusive act in fully violation of the accused rights and other entities. One sort of giving conclusions by experts was clearly specified in clause 26 of the code, they could be interrogated after expert analyses to clarify other circumstances or moving performance of a new expert. Expert duty to perform technical expertise and delivering expert results was openly defined in article 83.

On the other hand, exhibits and documents were provided by articles $27-30$ of this code, they were considered and admitted as evidence in criminal trials, considering their treatment (moods) and when the court progressed to a final finish on them. Of interest to the investigation of the judgment test material could be any substance, object, document, object related to the issue, authorship.

Outcomes confrontation has not been provided quite specific evidence in criminal trials, however, article 84 of the Penal Procedure Code envisaged the right of the investigators (under investigation) or court trial of the case to confront witnesses, defendants or witness to the defendant when the statements were contradictory. Article 136/1 of the Code highlighted that during the adjudication of the lawsuit, the court directly may hear statements of the defendants, witnesses, experts and review documents examines the items and material evidence.

Opposite to the main procedural principles enshrined in all democratic criminal procedural legislation, as well as logically it strongly predicted cases when proceeded with taking the statements of defendants and witnesses in cases;

- The defendant being tried in absentia or did not elaborate before the court - Witness was living away from the trial or when he had reasonable evidence for not coming out due to other work commitments. - When the removal of the defendant or witness from the courtroom under section 142 of this code was put.

Search tools, evidence, incorporated into Chapter V, articles 85 -96 of this code. Such provisions designated the presentation of evidence tools for identification and investigative experiment. Articles 85, 86, 88 and 89 established tools for the control of research evidence, conditions, manner and his form. The right to make and carry out control belonged to investigators and judges, providing that evidence were available enough and that somewhere in a place or (someone) a document was an important thing to resolve the issue, or to detect hidden people or corpses. The right of investigators of control was only in urgent cases and in other cases his decision should be sanctioned by the prosecutor. As a formal guarantee in this process the performance of an audit done in the mien of the individual who checked out, two informants and a popular member of the neighborhood council was anticipated during the control of places and people (when items and documents were related to the shell), they were set apart by the research worker or court decision seizure.

Sequestrations of items and displays of documents were exhibited by the detective or the court, the post-telegraph correspondence and any item whose retention was banned despite that being out of the issue was sequestered object.

The examination, demonstration of recognition and investigative experiments were provided by Articles 94,95 and 96 of this code. Clearly define the right of investigators and the tribunal to administer new evidence or to elucidate the circumstances of the case to take crime scene inspection, corpses, people, objects, documents, and carry out the procedure of recognition of people items or investigative experiment. Executing the above activities was necessary to be performed in the presence of two informants and experts with exceptional knowledge in the area of engineering and skill. During the above actions, skimmed drawing, necessary photographs were made, actions reflected in the respective minute surveillance, filing for recognition or investigatory experiment. Even in the code for the observations, wiretaps, undercover photographs and TV footage had no prediction, although they have been widely used by police force and investigation, especially for criminal offenses against the nation.

This code was improved over the years, changes which did not change the substance of its fiber. Changes to Law No. 6801 dated on 01.09.1983 and the Decision No. 7177 dated on 11.20.1987 which recognized and improved procedural position of prosecutor recognizing his right to exercise control over the investigations carried out by the investigative body, were deficient and had no effect in practice. Substantial modifications were realized to this code after years 90 with Law No. 7386 dated 05.08.1990 and the Law No. 7541 dated on 12.18.1991 "Republic of Albania 
Advocacy". It recognized the right of defense of the defendants with counsel, as and legally recognized rights and duties of professionals in penal defenders.

Based on the Basic Law No. 7491 dated 29.04.1991 "On the main constitutional provisions" were made significant alterations to the law No. 7536 dated 17.12.1991 "On Amendments to the Penal Procedure Code". This law abolished all criminal procedural provisions political character of the year. Within this law, every penal procedural provision of a political case and class was repealed. It defined content, tasks, criminal procedural legislation principles of a democratic character. The adoption by the defendant was recognized, the right of the court in making decisions independently and based on legal philosophy and evidence.

Law No. 7574 dated 24.06.1992 "On the constitution of justice and some modifications in the codes of criminal and civil procedure" sanctioned organization judicial system in district courts, appellate courts and the Court of Cassation.

Purposes of the court and other bodies of investigation were defined in conformity with international democratic standards. The prosecution was recognized as the controlling body that led inquiries and prosecution exercised own investigation, organized by and under the guidance of the prosecution. Final decisions on termination, suspension of investigation or send the lawsuit to trial, necessarily were approved by the prosecutor. It acknowledged the right of appeal of the defendant and his counsel, the decision for assigning security measure detention, as well as limits the discretion of the appeal by the tribunal. The above varieties and those established by Law No. 7717 dated 02.06.1993 "On Amendments to the Penal Procedure Code of Republic of Albania" sanctioned rights and guaranties of the defendants and their defense in criminal trials. The right to judicial advocates protection was recognized from the stage of detention, arrest or summoning a person to take penal responsibility, as well as his right to pass freely and privately with the defendant, even if stopped or delayed as well as mandatory defense of juvenile defendants. In this law, the adjustments were made as regards evidence and proof search tools, increasing procedural guarantees of people continued. In Article 3 therefore, obligation of notification was recognized in advance of counsel to conduct a procedural action with the defendant's right to guidance during the questioning process, of witnesses, defendants, and at the final stage of the investigation should be cognizant of all materials of the criminal event. The court was set aside to control as the sole agency to decide carrying out the dwelling control, except in the act, immediately after committing the crime, or the resulting danger to life and health of people, property or to preclude the commission of a criminal offense. It was also found that the seizure of correspondence, and any individual communication, made by a courtroom decision. It was absolutely necessary covering sequestration, having a spokesperson of the respective federal agency at hand or implement communication and agreement.

Despite these important democratic character changes in the early $90 \mathrm{~s}$, it must be told that the criminal procedural system that functioned until 1995, with the entry into force of the new code in its entirety, was purely inquisitorial and the inequality of the parties at all levels of the criminal process, especially during the investigation

\section{References}

Code of Criminal Procedure Republic of Albania 1953.

Code of Criminal Procedure's Republic of Albania 1980.

Code of Criminal Procedure's R.SH 1995.

Elezi I., (1997) "Historical development of criminal law in Albania", Albin, Tirane.

ECHR-European Convention on Human Right

International Covenant on Civil and Political Rights

Law No. 7536 dated 17.12.1991 "On Amendments to the Criminal Procedure Code of the Republic of Albania".

Luarasi A., Omari L., (1994) History of the State and law in Albania, $1^{\circ}$ edition, Tirane.

Omari L., Luarasi A., (2007) History of the State and law in Albania, 4th edition, Tirane.

Sahiti E., (1999), "The argument in penal procedure", Pristina, Kosovo.

Summary of international conventions ratified by the Republic of Albania, 2010 edition.

The Constitution of the Republic of Albania - 1998.

Vishinsky A., "The process of proving by Russian procedural law". Russia. 